\title{
Heritability and distribution of variation in degree of copper tolerance in Mimulus guttatus at Copperopolis, California
}

\author{
MARK R. MACNAIR, SUZANNE E. SMITH \& QUINTON J. CUMBES \\ Department of Biological Sciences, Hatherly Laboratories, University of Exeter, Prince of Wales Road, \\ Exeter EX4 4PS, U.K.
}

\begin{abstract}
The variation in degree of copper tolerance, its heritability and relationship with copper contamination of the soil and geographical location of sample, was studied on samples of seed collected from a large abandoned copper mine at Copperopolis, California. The realized heritability of variation in degree of tolerance at a high level of copper, $2 \mu \mathrm{g} \mathrm{cm}^{-3}$, is shown to be about 0.40 . The $F_{1}$ s of crosses between an upward and downward selection line and a non-tolerant line give intermediate values for tolerance. All seed samples taken from contaminated soils, and a number from populations downstream of the mine, have 100 per cent tolerant plants. Samples taken from upstream of the mine, and many populations in the vicinity, have a proportion of tolerant plants. The degree of tolerance of the samples is more variable, with rather steep clines for this character within the mine. The variation in degree of tolerance is related more to the location of the sample than to the absolute amount of copper contamination of the soil. Populations along the stream running through the centre of the mine wastes are more tolerant than populations taken from the edge of the wastes, which are more tolerant than populations collected from uncontaminated soils near the mine. The difference in steepness of the clines for the two characters, tolerance and degree of tolerance, suggests that selection against tolerance (the 'cost' of tolerance) acts more on degree of tolerance than on tolerance per se. These results are discussed in relation to the concept of genostasis.
\end{abstract}

Keywords: clines, cost of tolerance, ecological genetics, genostasis, natural selection, realized heritability.

\section{Introduction}

Heavy metal tolerance has proved to be one of the classic examples of microevolution and adaptation. Classic studies of British grasses on mine sites in the U.K. demonstrated how plants could rapidly evolve tolerance to a range of metals, producing distinct ecotypes that were often distributed extremely locally and showed rather precise adaptation to the particular local conditions. Detailed surveys of the mines at Drws-yCoed and Trelogan in North Wales by McNeilly (1968), Antonovics \& Bradshaw (1970) and Hickey \& McNeilly (1975) showed that there were very steep clines for copper tolerance in Agrostis capillaris (= tenuis) (Drws-y-Coed) and zinc tolerance in $A$. capillaris and Anthoxanthum odoratum (Trelogan) at the mine boundaries. At Drws-y-Coed the importance of gene flow to the shapes of the cline was apparent: the cline downwind of the mine was much less steep than across the direction of the prevailing wind. Except in the immediate vicinity of mines, the frequency of tolerant plants is very low (McNeilly \& Bradshaw, 1968). Several studies have shown that the degree of tolerance is correlated with the level of metal contamination: the most extensive is that of Jones \& Wilkins (1971) who found that the degree of lead tolerance in Festuca ovina was highly correlated with concentration of lead in 31 populations of this species. This correlation can also be found within single mine populations, when the degree of tolerance of a plant is correlated with the microenvironment in which it was located (Macnair, 1987). The steep clines for tolerance and the low frequency of tolerant plants in normal populations suggest that there is strong selection 
against tolerant plants in an uncontaminated environment and Hickey \& McNeilly (1975) have demonstrated the relatively low fitness of the tolerant ecotype in four different species.

All these studies have worked with relatively longlived perennials in a pasture type environment. In permanent pasture seedling establishment is relatively infrequent and clones of great antiquity have been reported (Harberd, 1961). Even in the harsh mine environment grasses can live for a long time: McNeilly (1979) reports that the half-life of Agrostis canina on Glasdir is 4-7 years, while Antonovics (1972) showed that zinc tolerant Anth. odoratum has a half-life of 2 years on Trelogan.

There has been a shortage of studies of these aspects of tolerance in species with a different ecology. Allen \& Sheppard (1971) showed that the monkey flower, Mimulus guttatus had evolved tolerance to copper and other metals on a variety of mines in Calaveras County, CA. M. guttatus has a very different ecology to these grasses: it is normally a hydrophilic species, growing in streams and damp places over most of Western North America. It does not appear to be a good competitor, being absent from normal pastures. Where conditions are favourable it is perennial but in places where the wet conditions are more seasonal, as in many parts of California, it is facultatively annual. It is as an annual that it probably grows on the mines in Calaveras County, although because of the absence of many of the plants that exclude it from mesic environments elsewhere, it is able to colonize not only streams but also drier parts of the tailings (Macnair et al., 1989).

Previous studies on copper tolerance in this species have concentrated on the genetics and mechanisms of tolerance (Allen \& Sheppard, 1971; Macnair, 1979, 1983; Robinson \& Thurman, 1986; Salt et al., 1989; De Miranda et al., 1990; Strange \& Macnair, 1991). Macnair (1983) showed that there was a single major gene giving copper tolerance, and has by repeated backcrossing inserted this gene into a non-tolerance genetic background to produce more or less isogenic lines (Macnair, 1981a; Macnair \& Watkins, 1983; Strange \& Macnair, 1991). The gene is expressed in the male gametophyte and some selection may act at this stage (Searcy \& Mulcahy, 1985; Searcy \& Macnair, 1990). Many mine plants show much greater tolerance than the tolerant isogenic lines, and Macnair (1983) suggested that this resulted from the action of other genes (modifiers). These modifiers are hypostatic to the tolerance gene, so their effects on the tolerance phenotype of an individual can only be detected in tolerant plants. A similar genetic determination for tolerance has been found in Silene vulgaris (Schat \& ten Bookum, 1992). Preliminary studies on the cost of tolerance
(Macnair \& Watkins, 1983) suggested that the tolerance gene per se did not show any evidence of being at a severe disadvantage in an uncontaminated environment.

This paper examines the distribution of tolerance in populations of $M$. guttatus in and around the large abandoned copper mine at Copperopolis, Calaveras $\mathrm{Co}, \mathrm{CA}$, and the heritability of the variations in tolerance identified.

\section{Materials and methods}

\section{Provenance of the plants}

Copperopolis and its environs. The large mine at Copperopolis, Calaveras Co, CA was last worked in 1945 (Kruckeberg \& Wu, 1992). It was visited in May 1985, April 1987 and April 1991. All the seeds studied from Copperopolis and its environs in this paper were collected in 1985. At this time plants were beginning to die back, so ripe seed could be collected from almost all individuals. Seed was collected in bulk by collecting capsules from at least 50 (normally many hundred) plants. Seed was winnowed and stored desiccated at $15^{\circ} \mathrm{C}$. A number of different subpopulations at Copperopolis, and different populations in the vicinity, were sampled. Figure 1 shows the location of the different subpopulations at Copperopolis: these locations were mapped accurately by taking bearings on fixed markers. The location of the other populations sampled are shown in Fig. 4. The tailings at Copperopolis extend for about $3 \mathrm{~km}$ along the bottom of a valley extending from Highway 4 to the dam and small lake to the south-east of the town (Fig. 1). The contaminated area is between 100 and $150 \mathrm{~m}$ wide, only extending up the valley side in the region of the smelter. The valley to the south of the smelter is uncontaminated.

All subpopulations at Copperopolis probably consist of annual plants: plants growing along the streams indicated in Fig. 1 can be large, up to $50 \mathrm{~cm}$ in height and producing large numbers of seeds, whereas plants growing on the tailings off the stream are mostly small, producing many fewer seeds (see Macnair et al., 1989).

Isogenic lines. The isogenic lines were derived from crosses made between plants collected by Sheppard in 1969 (Allen \& Sheppard, 1971) and non-tolerant plants from Stinson Beach collected by M.R.M. in 1977 (see Macnair, 1981a; Strange \& Macnair, 1991 for details). These lines consist of homozygous tolerant and non-tolerant plants which differ essentially only at the major gene for tolerance identified by Macnair (1983). 
Fig. 1 Map of Copperopolis showing the location of all subpopulations listed in Table 1. The shaded area shows the approximate extent of the contaminated tailings.

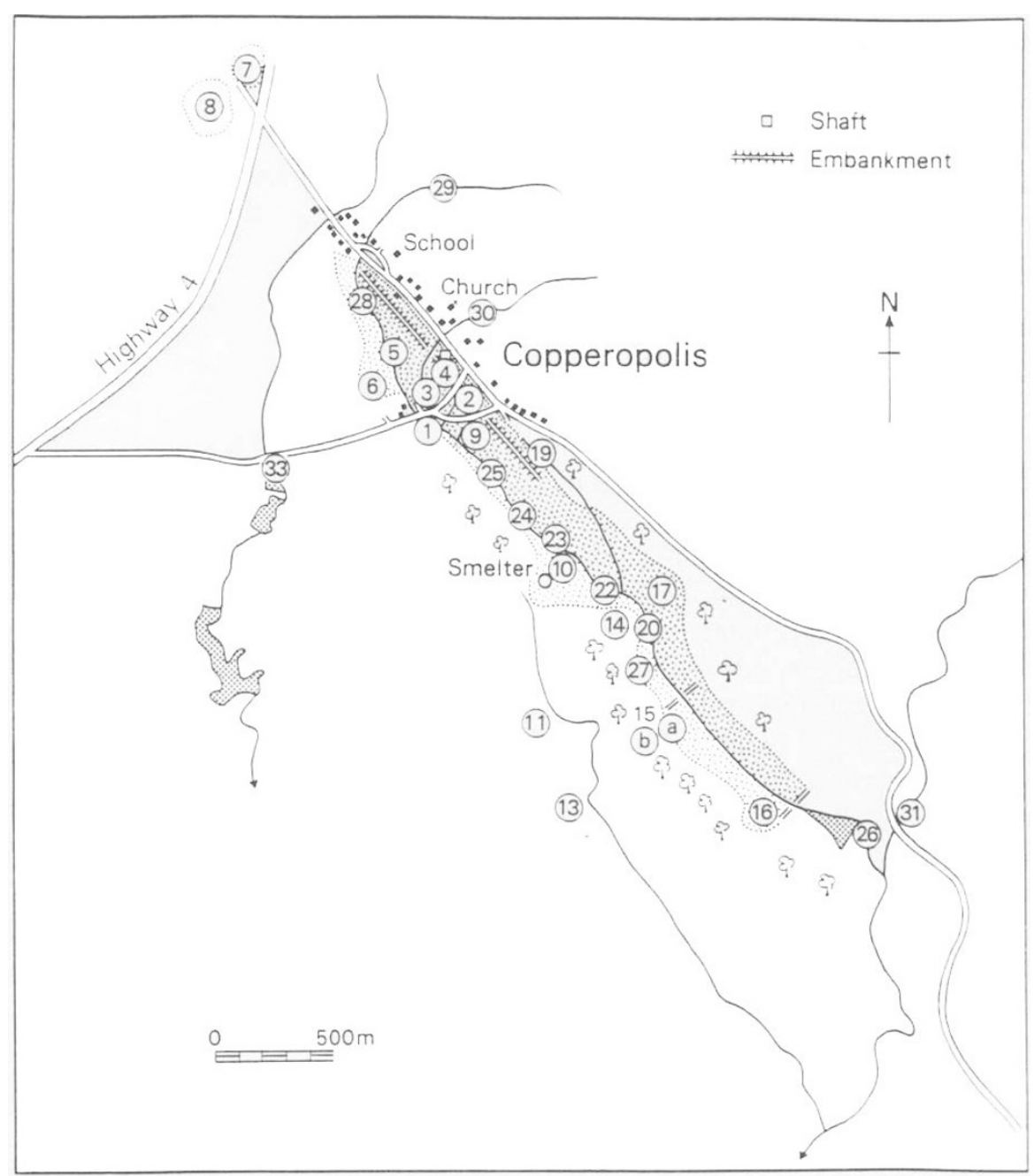

\section{Testing for tolerance}

Population sampling: Seeds were germinated in potting compost in $8 \mathrm{~cm}$ pots and transferred to trays $(212 \times 333 \mathrm{~mm})$ of John Innes compost number 2 (1987 and 1989 experiments) or coconut fibre supplemented with vitax feed (1992 experiment). Each tray held 60 seedlings. Seedlings were grown in a glasshouse under short days to prevent flowering and tested when they were between 5 and $15 \mathrm{~cm}$ tall. Seedlings were tested at one of two concentrations of copper $(0.5$ or $2.0 \mu \mathrm{g} \mathrm{cm}^{-3}$ as $\mathrm{CuSO}_{4}$ in calcium nitrate at $0.5 \mathrm{~g}$ $\left.1^{-1}\right)$ by using the same methods as Macnair (1983). The length of the longest root on a cutting after 7 days in the solution is used as the measure of its tolerance. Three experiments were conducted: one at $0.5 \mu \mathrm{g}$ $\mathrm{cm}^{-3}$ (1987) and two at $2 \mu \mathrm{g} \mathrm{cm}^{-3}$ (1989 and 1992).

Testing at $0.5 \mu \mathrm{g} \mathrm{cm}^{-3}$ distinguishes between tolerant and non-tolerant plants (Macnair, 1983) but at this level of copper most plants from Copperopolis do not show any significant inhibition of root growth. Thus very little of the between plant variation in root length at this level of copper is caused by variation in the degree or level of copper tolerance of the plants. At 2 $\mu \mathrm{g} \mathrm{cm}^{-3}$ copper, on the other hand, most plants show some inhibition of root growth, so that a proportion of the variation in root length is a function of the degree of tolerance of the individual tested. In this paper we are concerned with two separate aspects of tolerance: the difference between tolerance and non-tolerance (tested at $0.5 \mu \mathrm{g} \mathrm{cm}^{-3}$ copper) and the difference in degree of tolerance between tolerant individuals (tested at $2 \mu \mathrm{g} \mathrm{cm}^{-3}$ copper).

Dose-response curves. Individual plants were cloned and grown under short days in potting compost in $3^{\prime \prime}$ or $4 "$ pots. When the plants had produced sufficient 
sideshoots, similar sized cuttings were prepared and tested at various concentrations of copper as above.

Realized heritability of degree of tolerance. A selection experiment was set up from among all the plants tested in the 1989 experiment. A high line was selected for increased root length for two generations $\left(\mathrm{H}_{1}\right.$ and $\left.\mathrm{H}_{2}\right)$ at $2 \mu \mathrm{g} \mathrm{cm}^{-3}$ and a third generation $\left(\mathrm{H}_{3}\right)$ at $3 \mu \mathrm{g} \mathrm{cm}^{-3}$. A low line was selected for short root length at $1 \mu \mathrm{g}$ $\mathrm{cm}^{-3}$ copper. To avoid selecting for non-tolerance, only plants which produced sufficient roots to be classified as tolerant were selected. In each generation about 300 plants were grown up in trays and tested for tolerance and the 12-20 most extreme plants selected. These were then crossed in a half-diallel design and the seed pooled to give the next generation. In 1992, 15 randomly selected plants from each of the progeny of the first three generations were grown and tested at a range of concentrations.

The $\mathrm{H}_{3}$ and $\mathrm{L}_{3}$ plants selected to produce $\mathrm{H}_{4}$ and $\mathrm{L}_{4}$ were also crossed to a single plant from the isogenic non-tolerant line. Sixty plants from each family were raised in trays (see above) and tested at $1 \mu \mathrm{g} \mathrm{cm}^{-3}$ copper. Five plants from each of four families derived from the low selection line and from four families from the high selection line (both individuals and families chosen at random) were grown and tested at a range of concentrations.

\section{Determination of copper content on soils}

Soil samples were collected from the majority of sites sampled in 1985 and analysed using a modification of the mixed acid digestion of Allen (1989). Soils were air dried at $50^{\circ} \mathrm{C}$ and passed through a $2 \mathrm{~mm}$ stainless steel sieve. About $10 \mathrm{~g}$ of soil was then ground to a fine powder in an agate pestle and mortar. Powdered soil $(0.25 \mathrm{~g})$ was digested in $5 \mathrm{ml}$ nitric acid and $0.5 \mathrm{ml}$ sulphuric acid (both acids of aristar grade) at $100^{\circ} \mathrm{C}$ for $1 \mathrm{~h}$ and then at $170^{\circ} \mathrm{C}$ to remove the nitric acid. The solution was diluted, filtered and copper content determined on a Pye Unicam SP9 AAS. Standards were prepared from $1000 \mu \mathrm{g} \mathrm{cm}^{-3} \mathrm{BDH}$ Spectrosol solutions and were matched in acid concentration to the samples. They were also made to $10 \mu \mathrm{g} \mathrm{cm}^{-3}$ sodium to help overcome scatter effects.

\section{Results}

\section{Variation in degree of tolerance and its heritability}

Dose-response curves for the isogenic tolerant and non-tolerant lines are given in Fig. 2a, and for the first three generations of the high and low selection lines in
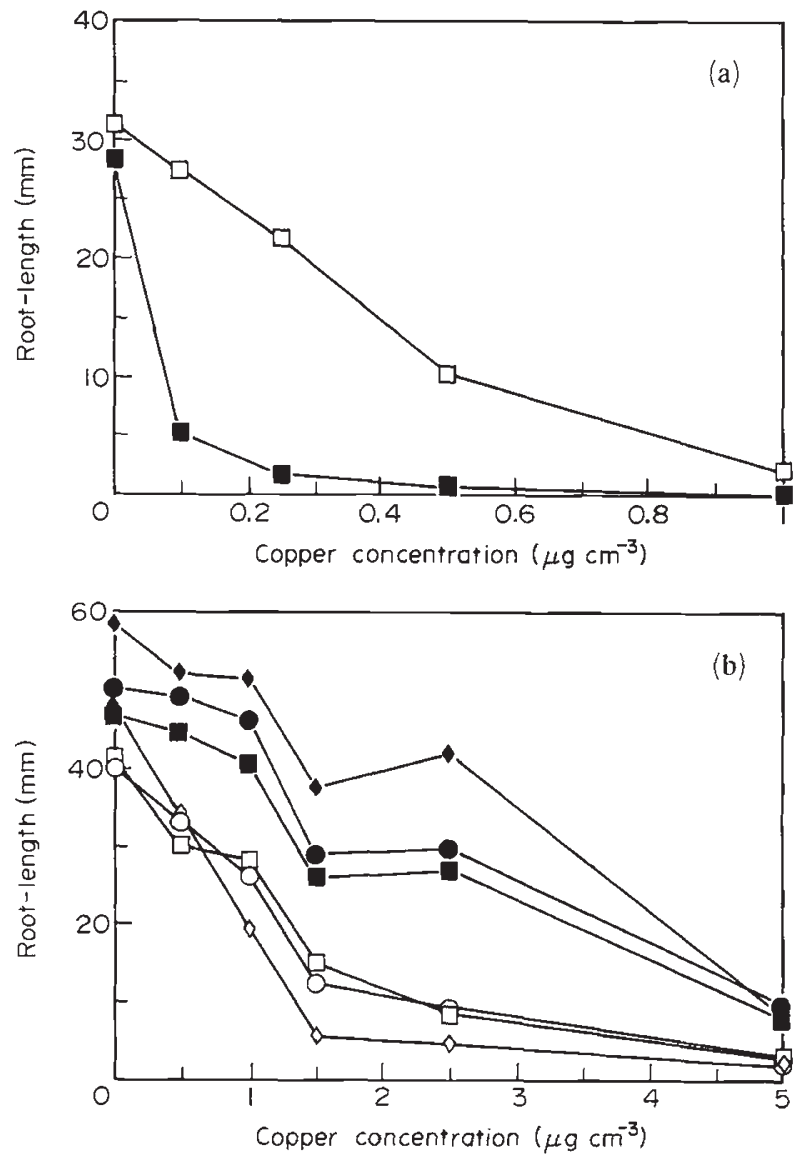

Fig. 2 Dose-response curves for (a) the isogenic tolerant ( $\square$ ) and non-tolerant ( lines and (b) for the first three generations of the selection line. Upward selection: filled symbols; downward selection: open symbols. Generation 1: squares; generation 2: circles; generation 3: diamonds. Note the difference in range of concentrations tested in (a) and (b).

Fig. 2b. These figures show (i) that testing at $0.5 \mu \mathrm{g}$ $\mathrm{cm}^{-3}$ distinguishes between tolerant and non-tolerant plants but that at this low level of copper most tolerant plants will be indistinguishable; and (ii) that selection for increasing and decreasing root length at a single concentration has produced differentiation in degree of tolerance. Analysis of variance of the data in Fig. $2 b$ shows that the overall difference in tolerance between the upward and downward selection lines is significant $\left\langle F_{5,447}=5.0, P<0.001\right)$ and that the response to selection in the three generations has been in different directions in the two lines $\left(F_{2,447}=5.0, P=0.007\right)$. The first two generations of the upward selection line were conducted at the same concentration of copper and so it is possible to calculate realized heritabilities (Falconer, 1989). $\mathrm{H}_{1}$ gives a value of 0.37 , while $\mathrm{H}_{2}$ gives 0.43 (overall 0.39).

Further evidence for a genetic difference between upward and downward selection lines was obtained 


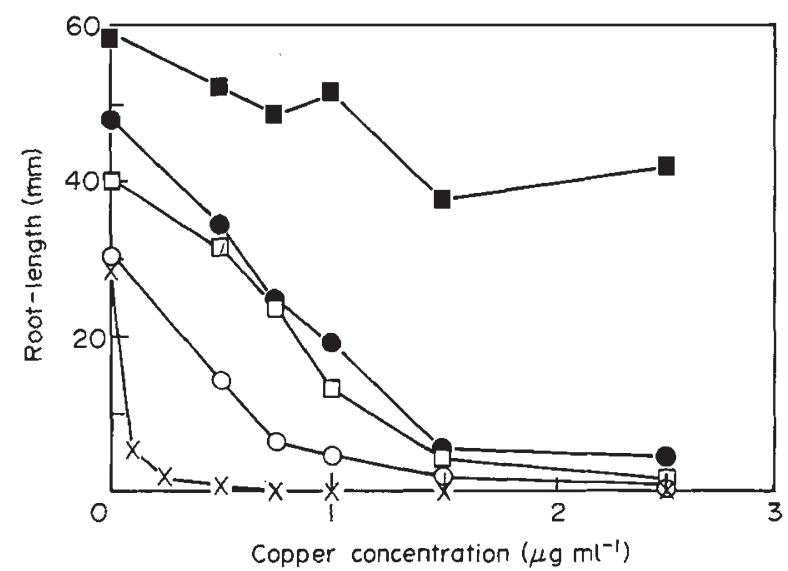

Fig. 3 Mean dose-response curves of $20 \mathrm{~F}_{1}$ plants from crosses between $\mathrm{H}_{3}(\square)$ and $\mathrm{L}_{3}(\mathrm{O})$ plants and the non-tolerant isogenic line. The dose-response curves of the $\mathrm{H}_{3}(-)$ and $\mathrm{L}_{3}(\bullet)$ generations and the non-tolerant isogenic line $(x)$ are also shown.

from the crosses between the $\mathrm{H}_{3}$ and $\mathrm{L}_{3}$ plants and the non-tolerant isogenic line. The progeny of these crosses had very different mean root lengths and distribution of root lengths when tested at $1 \mu \mathrm{g} \mathrm{cm}^{-3}$ : whereas 84.7 per cent of the plants with an $\mathrm{L}_{3}$ individual as a parent had root lengths of $12 \mathrm{~mm}$ or less, the corresponding figure for the progeny of $\mathrm{H}_{3}$ was 25.7 per cent.

Figure 3 gives the mean dose-response curves for the 20 plants selected from these crosses. Also replotted on this figure are the mean dose-response curves for the generation from which the tolerant parents were taken and the non-tolerant parent. It can be seen from this that the $F_{1}$ progeny of both high and low selection lines have dose-response curves roughly intermediate between their non-tolerant and tolerant parents.

\section{Distribution of tolerance and degree of tolerance at Copperopolis}

Table 1 gives the number of tolerant and non-tolerant plants (distinguished as to whether they formed roots at a testing concentration of $0.5 \mu \mathrm{g} \mathrm{cm}^{-3}$ copper) in each of the seed samples from Copperopolis. It also gives the total copper content of the soil at the site: sites with less than about 300-400 $\mu \mathrm{g} \mathrm{g}^{-1}$ copper did not appear to be affected by copper contamination. All the populations from the mine had effectively 100 per cent tolerant plants. All the populations to the south of the mine (Cop33, Cop11 and Cop13) also had 100 per cent tolerants. The populations to the north (Cop29, Cop30 and Cop31) upstream of the mine, segregated. Two populations were collected from uncontaminated woodland adjacent to the southern edge of the tailings (Cop14 and Cop15b). One of them (Cop15b) also segregated for tolerance, even though the other (Cop14) did not.

Figure 4 gives the proportion of plants tolerant at $0.5 \mu \mathrm{g} \mathrm{cm}^{-3}$ in 15 populations in the vicinity of Copperopolis. The majority of populations segregated some tolerant plants, albeit at low (less than 5 per cent) frequency. However, a number of populations had a higher frequency, even though there was no apparent copper contamination. There are a number of other copper mines in the area (marked in Fig. 4): at all these mines $M$. guttatus can be found and all plants are tolerant (Allen \& Sheppard, 1971; unpublished data).

Also given in Table 1 are the results of testing these populations at $2 \mu \mathrm{g} \mathrm{cm}^{-3}$. This test was replicated on two occasions, in 1989 and 1992 . The results are given in two ways. Firstly, as the mean root length. There was no significant overall difference in mean root length between the two replicates $\left(F_{1,25}=1.10\right.$, ns $)$, so the overall mean is given. However, the distribution of root lengths is highly skewed and so the mean root length may be a rather poor statistic to describe these distributions. Also given is the proportion of each population that exceeds the overall third quartile (p3Q). This statistic will more accurately pull out those plants which are rooting with some vigour, and thus are most likely to be highly tolerant, at this concentration of copper. This proportion is obviously highly correlated with the mean $(r=0.912, P<0.001)$.

Figure 5 shows the relationship between the $\mathrm{p} 3 \mathrm{Q}$ of populations and copper content of the soil. The regression of $\mathrm{p} 3 \mathrm{Q}$ on copper content is significant $\left(F_{1,28}=6.31, P=0.02\right)$. However, this relationship is very dependent on the cluster of points of low contamination and low mean tolerance; among the populations with moderate to high copper contamination there is no clear relationship. Figure 6 plots $p 3 Q$ as pie diagrams on the map of Copperopolis. It appears that samples along the main axis of the mine have a higher tolerance than those further away. To investigate this further, the populations have been classified into five groups: 1 : north group; 3 : along the main stream through the mine; 5 : south group; 2 and 4 are intermediate populations to the north and south, respectively. Table 1 lists the groups that the populations fall into on this classification. Populations more than $500 \mathrm{~m}$ from Copperopolis, and populations Cop7 and Cop8, which are not part of the main complex, are not included. Both the mean tolerance of populations (as measured by $\mathrm{p} 3 \mathrm{Q}$ or mean root length) at $2 \mu \mathrm{g} \mathrm{cm}^{-3}$ and copper content of the soil vary significantly between groups (p3Q: $\quad F_{4,24}=11.38, \quad P<0.001 ; \quad \mathrm{Cu}: \quad F_{4,24}=4.52$, $P=0.007$ ), with tolerance and copper content being 
Table 1 Copper concentration $\left(\mu \mathrm{g} \mathrm{g}^{-1}\right)$, North/South group, and mean tolerance of populations at 0.5 and $2 \mu \mathrm{g} \mathrm{cm}^{-3} \mathrm{copper}$. pT: proportion of population tolerant at $0.5 \mu \mathrm{g} \mathrm{cm}^{-3}$; p3Q: proportion of plants above overall third quartile; $N$ : number of plants tested at each concentration; mean root length: mean root length $(\mathrm{mm})$ of tolerant plants at $0.5 \mu \mathrm{g} \mathrm{cm}^{-3}$, or of all plants at $2 \mu \mathrm{g} \mathrm{cm}^{-3}$

\begin{tabular}{|c|c|c|c|c|c|c|c|c|}
\hline \multirow[b]{2}{*}{ Population } & \multirow[b]{2}{*}[\mathrm{Cu}]{} & \multirow[b]{2}{*}{$\mathrm{N} / \mathrm{S}$ group } & \multicolumn{3}{|c|}{ Tolerance at $0.5 \mu \mathrm{g} \mathrm{cm}^{-3}$} & \multicolumn{3}{|c|}{ Tolerance at $2 \mu \mathrm{g} \mathrm{cm}^{-3}$} \\
\hline & & & $\mathrm{pT}$ & $N$ & Mean root length & $\mathrm{p} 3 \mathrm{Q}$ & $N$ & Mean root length \\
\hline Cop1 & 3380 & 3 & 1.00 & 117 & 40.32 & 0.441 & 111 & 12.59 \\
\hline Cop2 & 3535 & 2 & 1.00 & 107 & 42.02 & 0.494 & 79 & 13.21 \\
\hline Cop3 & 13190 & 3 & 1.00 & 112 & 34.14 & 0.430 & 158 & 13.97 \\
\hline Cop3b & 15500 & 3 & 1.00 & 111 & 40.99 & 0.303 & 76 & 9.86 \\
\hline Cop4 & 3070 & 2 & 1.00 & 115 & 38.13 & 0.440 & 91 & 12.13 \\
\hline Cop5 & 4957 & 3 & 1.00 & 95 & 41.12 & 0.313 & 300 & 7.81 \\
\hline Cop6 & 5345 & 4 & 1.00 & 114 & 37.06 & 0.386 & 88 & 10.37 \\
\hline Cop7 & 3675 & - & 1.00 & 109 & 46.64 & 0.524 & 84 & 15.84 \\
\hline Cop8a & 1520 & - & 1.00 & 104 & 38.61 & 0.381 & 118 & 18.76 \\
\hline Cop8b & 2736 & - & 1.00 & 113 & 50.42 & 0.471 & 140 & 9.76 \\
\hline Cop8c & ND & - & 1.00 & 102 & 31.39 & 0.136 & 81 & 5.25 \\
\hline Cop9 & 3850 & 2 & 1.00 & 98 & 43.03 & 0.404 & 99 & 10.03 \\
\hline Cop10 & 8890 & 4 & 1.00 & 116 & 39.86 & 0.120 & 83 & 5.54 \\
\hline Cop11 & 335 & 5 & 1.00 & 108 & 36.88 & 0.170 & 94 & 6.22 \\
\hline Cop13 & 205 & 5 & 1.00 & 107 & 30.97 & 0.112 & 98 & 7.00 \\
\hline Cop14 & 1165 & 4 & 1.00 & 111 & 28.69 & 0.048 & 104 & 3.55 \\
\hline Cop15a & 4895 & 4 & 0.95 & 109 & 39.58 & 0.129 & 194 & 3.55 \\
\hline Cop15b & 163 & 4 & 0.82 & 112 & 28.35 & 0.000 & 128 & 1.36 \\
\hline Cop16 & 2200 & 4 & 1.00 & 114 & 36.97 & 0.192 & 130 & 6.02 \\
\hline Cop17 & 779 & 2 & 1.00 & 103 & 38.49 & 0.088 & 80 & 3.30 \\
\hline Cop19 & 1335 & 2 & 0.99 & 110 & 39.97 & 0.316 & 76 & 9.54 \\
\hline Cop20 & 5595 & 3 & 1.00 & 95 & 46.00 & 0.497 & 177 & 14.62 \\
\hline Cop22 & 1018 & 3 & 1.00 & 52 & 46.31 & 0.333 & 42 & 13.10 \\
\hline Cop23 & 10215 & 3 & 1.00 & 114 & 33.15 & 0.429 & 28 & 15.43 \\
\hline Cop24 & 6580 & 3 & 1.00 & 112 & 45.95 & 0.406 & 101 & 15.30 \\
\hline Cop25 & 7970 & 3 & 1.00 & 157 & 48.20 & 0.462 & 91 & 11.30 \\
\hline Cop26 & 3485 & 3 & 1.00 & 82 & 45.51 & 0.318 & 170 & 9.88 \\
\hline Cop27 & 1874 & 4 & 1.00 & 109 & 43.30 & 0.300 & 90 & 7.70 \\
\hline Cop28 & 12530 & 3 & 1.00 & 115 & 49.68 & 0.388 & 80 & 11.58 \\
\hline Cop29 & 108 & 1 & 0.07 & 89 & 35.79 & 0.007 & 153 & 0.56 \\
\hline Cop30 & 113 & 1 & 0.69 & 113 & 31.36 & 0.030 & 68 & 1.58 \\
\hline Cop31 & 192 & 1 & 0.35 & 102 & 20.88 & 0.000 & 56 & 0.73 \\
\hline Cop33 & 360 & 5 & 1.00 & 106 & 38.09 & 0.238 & 130 & 9.06 \\
\hline
\end{tabular}

higher in group 3 than in groups 2 or 4 . However, when copper content was included as a covariate in the analysis of variance of the difference between groups for mean tolerance (measured as $\mathrm{p} 3 \mathrm{Q}$ ), it was not significant $\left(F_{1,23}=0.42\right.$, ns $)$. This indicates that, once location has been taken account of, copper contamination does not explain any of the variance in mean copper tolerance of populations. It is thus not possible from this analysis to show any role for degree of contamination as a determinant of mean level of tolerance of populations. Inspection of Table 1 and Fig. 6 shows (i) that the mean tolerance of a population is much more affected by distance away from the central axis of the mine than the proportion of tolerants; and (ii) all populations that segregate non-tolerant individuals also have a low mean tolerance at $2 \mu \mathrm{g} \mathrm{cm}^{-3}$. This suggests that the clines for degree of tolerance are steeper than the clines for the proportion of tolerant plants.

\section{Discussion}

The measure of copper tolerance used in this paper is the length of roots formed by plants exposed to various 
Fig. 4 Map of the Copperopolis area showing the proportion of tolerant plants found in 15 populations growing in uncontaminated soils. Sample sizes range from 63 to 199 (mean 96). Triangles indicate copper mines which all possess populations of $M$. guttatus with 100 per cent tolerant plants.

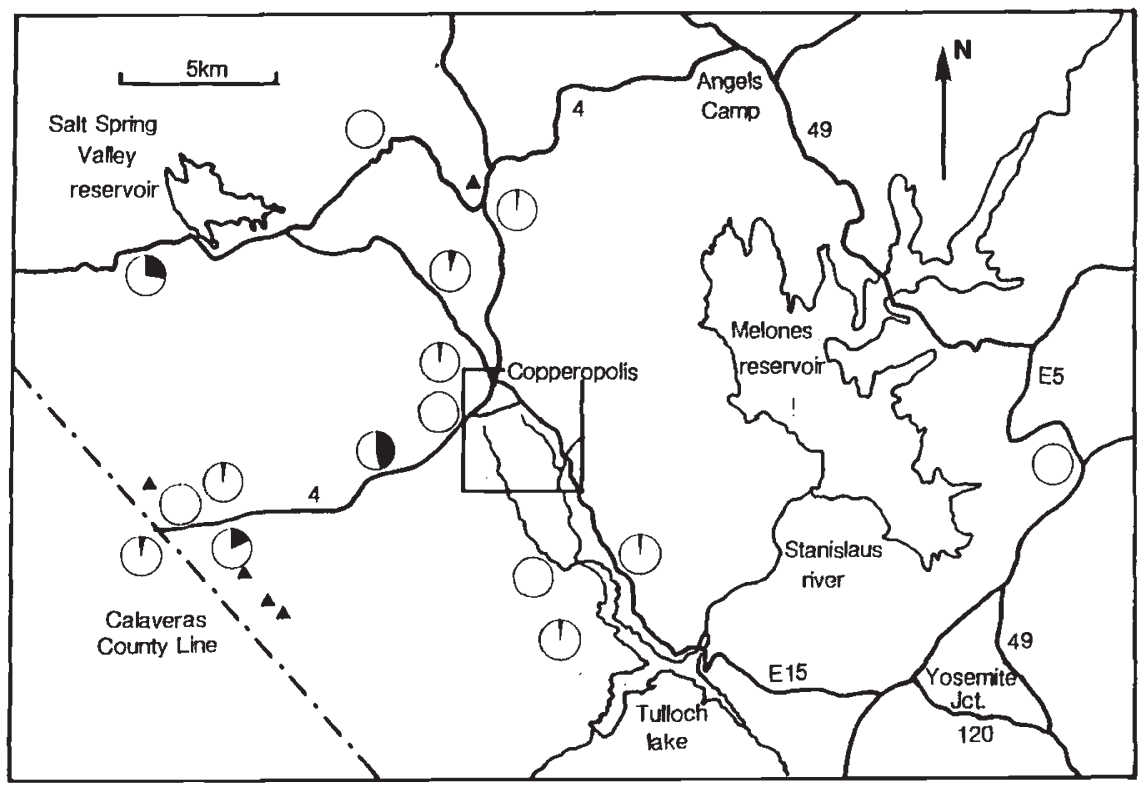

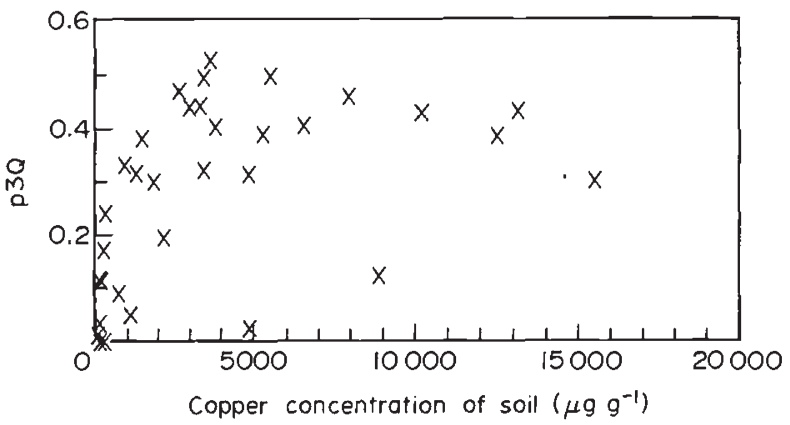

Fig. 5 Relationship between $\mathrm{p} 3 \mathrm{Q}$ (the proportion of plants in a sample with root lengths greater than the overall third quartile) and the copper content of the soil from which the sample was collected.

levels of copper in solution. Previous work (Macnair, 1983) has shown that there is a single major gene that determines whether a plant is tolerant or not. Testing at $0.5 \mu \mathrm{g} \mathrm{cm}^{-3}$ enables plants homozygous or heterozygous for this gene (tolerants) to be distinguished from non-tolerants. Because most tolerant plants, however, show rather little root inhibition at this low level of copper, further investigation into variation in degree of tolerance has to be undertaken at higher levels of copper.

The selection experiments, and the crosses to the non-tolerant line, show that the variation in root length detected at higher levels of copper is heritable. Although some of the differences found between the selection lines can be attributed to selection for innate differences in root length (see Fig. 2), it is clear that a major part of the variance is genuinely attributable to differences in tolerance. It is remarkable that the realized heritability of copper tolerance found in this experiment ( 39 per cent) is almost exactly the same as the value obtained by Al-Hiyaly et al. (1993) for zinc tolerance in Agrostis capillaris. Because all the plants studied in the selection experiment are homozygous for the major tolerance gene, the genetic variation detected by these experiments is due to additional genes, modifiers (Macnair, 1983).

When the tolerance gene was placed into a nontolerant genetic background by repeated backcrossing (Macnair, 1981a; Strange \& Macnair, 1991) it showed complete dominance (Strange \& Macnair, 1991). In contrast, the $\mathrm{F}_{1} \mathrm{~s}$ of the crosses between $\mathrm{H}_{3}$ and $\mathrm{L}_{3}$ plants are approximately intermediate between the two parents (Fig. 3), suggesting that the modifiers act more or less additively.

The study of the distribution of tolerance at Copperopolis gave contrasting results, depending on the level of copper used to test the plants. Consider first the distribution of the character tolerance, rather than degree of tolerance. All the populations on contaminated soil have 100 per cent tolerant plants but so also do a number of other populations close to the mine, particulrly Cop11, Cop13, Cop14 and Cop33. Populations to the north of the mine, and many of those at some distance away, still have a substantial proportion of tolerant plants.

In contrast, the character degree of tolerance shows much more variation within and between these popula- 


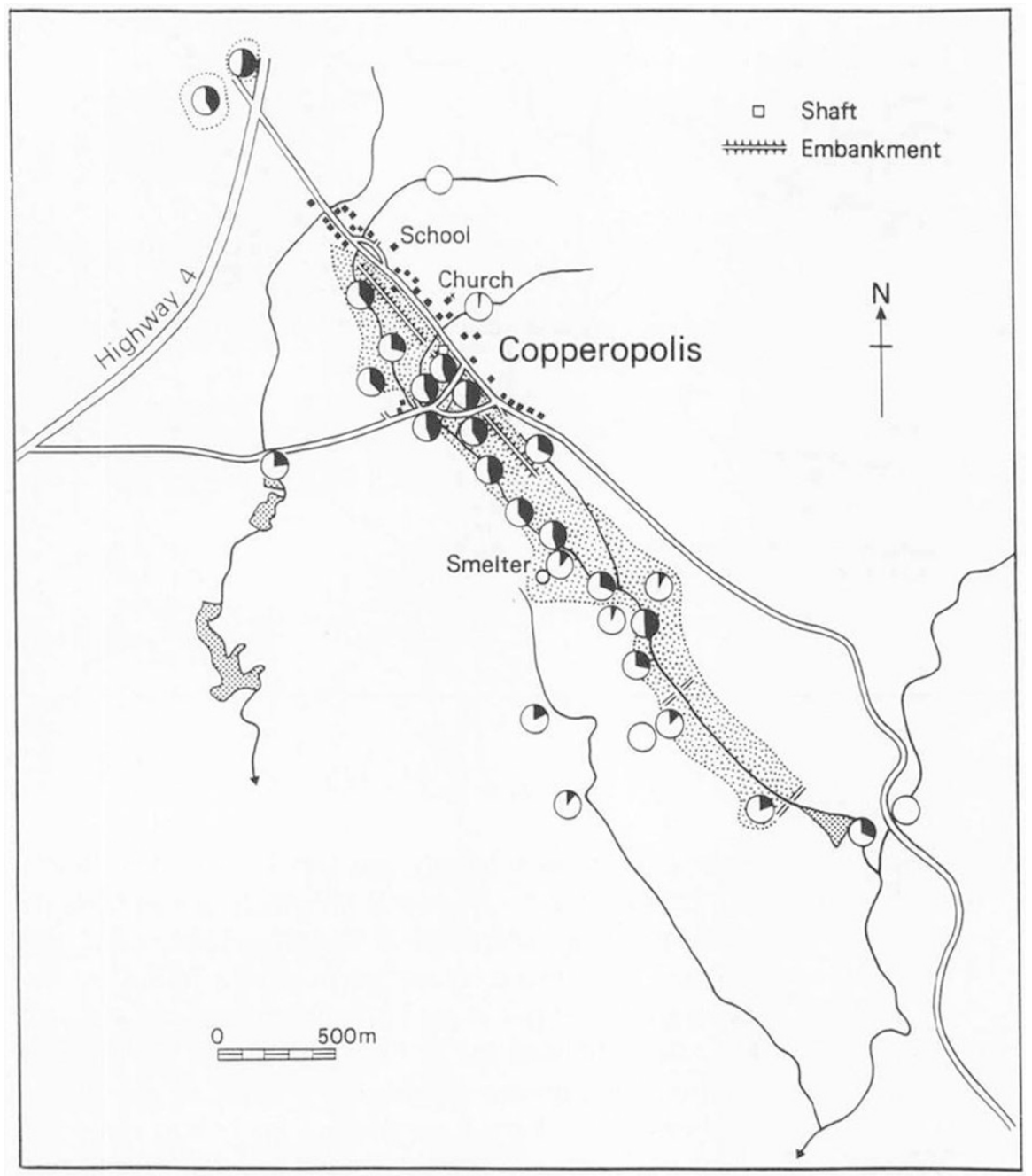

Fig. 6 Map of Copperopolis showing the $\mathrm{p} 3 \mathrm{Q}$ of all Copperopolis samples. For sample sizes, see Table 1. tions, with much steeper clines being apparent. In particular, all populations with a significant proportion of non-tolerants within them also have very low levels of mean tolerance. To a certain extent this is inevitable: plants which do not root at $0.5 \mu \mathrm{g} \mathrm{cm}^{-3}$ will also not root at $2.0 \mu \mathrm{g} \mathrm{cm}^{-3}$, so that the inclusion of these plants in the population samples must depress their means. However, it is possible to show that even taking account of this, they have a very low level of tolerance. If we pool the results for all populations at Copperopolis (Cop15b, Cop29, Cop30, Cop31) that have more than 5 per cent non-tolerants, the total proportion of tolerants in these samples is 0.509 . We would expect 182 plants tolerant at $0.5 \mu \mathrm{g} \mathrm{cm}^{-3}$ in these populations when tested at $2 \mu \mathrm{g} \mathrm{cm}^{-3}$. Yet there are only three plants in these populations that had root lengths that lie above the third quartile, a proportion which is very significantly less than the 25 per cent expected if they had the same tolerance as the whole data set.
The steepness of a cline depends upon the strength of selection acting on the character and the amount of gene flow across it (Endler, 1977). Gene flow in $M$. guttatus can occur in a number of ways. Pollination is primarily effected by bumble-bees, which will generally tend to forage in a local area, so that long distance gene flow by pollinators is unlikely. Seeds are small, and capsules form 'shakers' that allow some seed dispersal by wind. However, the relatively low height of most plants will mean that most seeds will fall within a few metres of their maternal parent. Waser et al. (1982) and Vickery et al. (1986) found that more than 50 per cent of $M$. guttatus seed fell within $0.5 \mathrm{~m}$ of the parent plant. As this is a hydrophilic species, many plants will be growing close to running water and long distance dispersal is much more likely by this method, but exclusively downstream. Waser et al. (1982) found the median dispersal distance to be $275 \mathrm{~m}$ downstream in a study of a natural population of this species in Utah. In addition. M.R.M. has seen small whirlwinds on 
Copperopolis carry dust (and, presumably, seeds) to more than $20 \mathrm{~m}$; large mammals (deer and cattle) eat the seeds and some survive their passage through the gut (Vickery et al., 1986): these two agencies could be responsible for the occasional longer distance transport in any direction. The pattern that the clines are steeper to the NE (upstream) than SE and SW (downstream) is consistent with the probable asymmetry in gene flow caused by water dispersal of seeds. This parallels the study of McNeilly (1968) who found similar differences between two clines that could be related to differences in gene flow, in this case prevailing wind direction.

Another factor affecting gene flow is population density and fecundity: genes will flow preferentially from high density/high seed productivity areas to low density areas. Regions of low population density can create steps in clines because of an interruption to gene flow (Endler, 1977). At Copperopolis, the populations along the main stream have much larger plants producing far more flowers and seeds per flower than populations in the drier areas and the tailings, where plant size is small, and the number of flowers and seeds per flower is correspondingly reduced (Macnair et al., 1989). The low density/low productivity populations on the tailings away from the main stream are also more susceptible to fluctuations in population size arising from drought and unfavourable conditions. Thus between 1985 (when the populations studied here were collected) and 1991 California suffered 5 years of drought. The winter of 1990/91 was particularly unusual: low autumn rainfall resulted in little Mimulus growth during the early winter and a very cold January killed off many individuals. The result was that in 1991, many of the populations, particularly those away from the main stream, were much reduced in size or had disappeared. For instance, at Cop17, which in 1985 had numbered many thousand plants, M.R.M. was unable to find a single seedling in 1991. At Cop16, Cop15 and Cop14, population sizes had been reduced to very low levels and the seedlings were small and thus relatively unfecund. In contrast, the plants along the main stream, particularly in Cop23 and Cop22, were large and numerous. Although the relative roles of recolonization from the nearby populations or from a residual seed-bank are unknown in this species, it is obvious that there is potential for considerable gene flow from the central populations into the more peripheral ones.

However, presumably gene flow is the same for both characters, tolerance and degree of tolerance. The differences in shape of the clines suggests that there are differences in the strength of selection acting on them. Considering first the character tolerance, vis-à-vis non- tolerance, the high frequency of tolerants in some populations a long way from Copperopolis and the 100 per cent frequency in populations in uncontaminated soils downstream of the mine suggest that the selection acting against tolerant plants in uncontaminated soils may not be very strong. This is consistent with the results of Macnair \& Watkins (1983) who were unable to find any difference in fitness between tolerant and non-tolerant plants in a glasshouse experiment.

In contrast, the steep clines in degree of tolerance away from the central stream suggest that there may be selection against plants of excess tolerance in the sites near the edge of the mine. These sites have less copper contamination on average than the central sites but variation in copper content explains no more of the variation in tolerance than variation in location, so it is not certain that the reduction in tolerance is caused by a reduction in copper. The sites away from the stream are drier than the stream sites and tend to support facultatively smaller plants that mature earlier. It is possible that this environment would impose different selection pressures on tolerance.

The nature of the selection against tolerance (the 'cost of tolerance') is still obscure. Selection against highly tolerant mine plants in uncontaminated soils was demonstrated by Hickey \& McNeilly (1975), and Ernst et al. (1990) have reported that highly tolerant Silene vulgaris is at a disadvantage compared with non-tolerant plants. Various possible causes of the disadvantage have been suggested. There have been some reports that tolerant plants show a stimulation of growth at low levels of metal (Antonovics et al., 1971; Macnair, 1981b). This would suggest that tolerant plants may have a higher requirement for the metal, which may be difficult to satisfy in normal soils. However, the dose-response curves reported here give no indication of a stimulation of copper at low levels, although even the lowest concentrations utilized here are probably far higher than those found in natural soils. Ernst et al. (1990) have also suggested that the mechanism of tolerance (as yet unknown) may have an energetic cost that results in tolerant plants being at a disadvantage. Wilson (1988) suggested that tolerant plants have a lower relative growth rate than non-tolerants. However, all the studies indicating a 'cost' to tolerance have compared plants from different populations. The experimental designs automatically introduce linkage disequilibrium between tolerance genes and any other genes differentiating mine populations. It is possible that a general feature of stress resistance is lower competitive ability and growth rates (Grime, 1979; Chapin, 1980; Hoffman \& Parsons, 1991). Mines are highly stressful habitats for many reasons and thus the 
disadvantage to the tolerant ecotype may be associated with these other characters. The problems of linkage disequilibrium should be less acute in a within-population study such as that performed here. However, while an evolutionary 'cost' of tolerance is indicated by the clines reported here, it is not at all clear how the cost arises. An analysis of correlated characters within the selection line may help to shed light on this problem in the future.

A further factor influencing the shapes of phenotype clines is the dominance of the character studied. A fully dominant gene will have a more convex cline than a gene showing additive architecture, given equal gene frequencies. While tolerance shows full dominance (Strange \& Macnair, 1991), the degree of tolerance appears to show greater additivity (Figs. 2b, 4). This may account for some of the difference in shape of the clines, particularly to the north of the mine, but is unable to account for the difference in the shapes of the clines to the south.

The results described in this paper are in contrast to most of the studies of grasses in Britain (McNeilly, 1968; Hickey \& McNeilly, 1975; Antonovics \& Bradshaw, 1970; McNeilly \& Bradshaw, 1968), where very steep clines for tolerance have been found at the edge of mines, with a generally low frequency of tolerant plants in uncontaminated populations more than a few hundred metres from the mine. An exception was noted by Khan (quoted in Bradshaw, 1971), who showed that tolerant individuals can be found in seed samples a long way downwind of the Parys Mountain mine on Anglesey. These authors (except Khan) all studied adult plants collected from the wild, whereas the populations studied here were all collected as seeds. McNeilly (1968) found that the shapes of the clines for adults and seed of $A$. capillaris were different, owing to substantial gene flow in this wind pollinated species. It might thus be suggested that the differences reported here between the results for grasses and $M$. guttatus are simply a reflection of this difference in the life-history stage at which the plants were sampled. This is unlikely. Substantial differences between adult and seed clines can only occur where there is significant gene flow via pollen along the cline. This can occur in wind-pollinated grasses, where mine and non-mine populations are almost continuous, but, as argued above, is likely to be much less in a bumblebee pollinated species growing in discontinuous patches as in Mimulus guttatus. In this species, seed samples should accurately reflect the gene frequencies in the adult plants from which they were collected.

The results reported here indicate that considerable genetic variance for tolerance persists within this population. Bradshaw (1991) has argued that in many cases evolution may be constrained by the lack of genetic variation and has cited the case of metal tolerance to illustrate this constraint for which he has coined the term 'genostasis'. In the case of the initial evolution of tolerance he is undoubtedly correct: only populations of species that possess appropriate genetic variation can evolve tolerance to any particular metal (Ingram, 1988; Al-Hiyaly et al., 1988, 1993; Bradshaw, 1991). However, he has also argued that populations have been prevented from populating the most contaminated areas of mines by the lack of variation: populations have been selected for increased tolerance as far as they can go and then lose the variation for further progress. Certainly at Copperopolis this would appear not to be so: the population possesses appropriate variation, and artificial selection can produce in only three generations a population considerably more tolerant than any population at Copperopolis (Fig. 2a). As in other mines, there are many uncolonized sites, and possibly a lack of tolerance is a contributory factor to the inability of $M$. guttatus to colonize these sites. The fact that in the field natural selection has not increased tolerance presumably reflects the conflicting selection acting on this character.

\section{Acknowledgements}

Part of this research was funded by NERC grant number GR3/8306. Field trips to California were funded by the Royal Society, the British Ecological Society and the University of Exeter Research Fund. Receipt of this support is gratefully acknowledged. We are grateful to the owners of the Copperopolis mine for access to the study site.

\section{References}

AL-HiYAly, S. A., MCNEILly, T. AND BRADSHAW, A. D. 1988. The effects of zinc contamination from electricity pylons evolution in a replicated situation. New Phytol., 110, 571-580.

AL-HIYALY, S. A. K., MCNEILLY, T., BRADSHAW, A. D. AND MORTIMER, A. M. 1993. The effect of zinc contamination from electricity pylons. Genetic constraints on selection for zinc tolerance. Heredity, 70, 22-32.

ALLEN, S. E. 1989. Chemical Analysis of Ecological Materials, 2nd edn. Blackwell, Oxford.

ALLEN, W. R. AND SHEPPARD, P. M. 1971. Copper tolerance in some Californian populations of the monkey flower, Mimulus guitatus. Proc. R. Soc. Lond. B, 177, 177-196.

Antonovics, J. 1972. Population dynamics of the grass Anthoxanthum odoratum on a zinc mine. J. Ecol., 60, 351-365. 
ANTONOVICS, J. AND BRADSHAw, A. D. 1970. Evolution in closely adjacent populations. VIII. Clinal patterns at a mine boundary. Heredity, 25, 349-362.

ANTONOVICS, J., BRADSHAW, A. D. AND TURNER, R. G. 1971. Heavy metal tolerance in plants. Adv. Ecol. Res., 7, 1-85.

BRADSHAW, A. D. 1971. Plant evolution in extreme environments. In: R. Creed (ed.) Ecological Genetics and Evolution: Essays in Honour of E. B. Ford. Blackwell, Oxford, pp. 20-50.

BRADSHAW, A. D. 1991. Genostasis and the limits to evolution. Phil. Trans. R. Soc. Lond. B, 333, 289-305.

ChAPIN, F. S. 1980 . The mineral nutrition of wild plants. Ann. Rev. Ecol. Syst., 11, 233-260.

DE MIRANDA, J. R., THOMAS, M. A., THURMAN, D. A. AND TOMSETT, A. B. 1990. Metal-lothionein genes from the flowering plant Mimulus guttatus. FEBS Lett., 260, 277-280.

ENDLER, I. A. 1977. Geographical Variation, Speciation and Clines. Princeton University Press, Princeton, NJ.

ERNST, W. H. O., SCHAT, H. AND VERKLEIJ, J. A. C. 1990. Evolutionary biology of metal resistance in Silene vulgaris. Evol. Trends in plants, 4, 45-51.

FALCONER, D. S. 1989. Introduction to Quantitative Genetics, 3rd edn. Longman, Harlow.

GRIME, J. P. 1979. Plant Strategies and Vegetation Processes. John Wiley, Chichester.

HARBERD, D. J. 1961. Observations on population structure and longevity of Festuca rubra L. New Phytol., 60, 184-206.

HICKEY, D. A. AND MCNEILlY, T. 1975. Competition between metal tolerant and normal plant populations. A field experiment on normal soil. Evolution, 29, 458-464.

HOFFMANN, A. A. AND PARSONS, P. A. 1991. Evolutionary Genetics and Environmental Stress. Oxford University Press, Oxford.

INGRAM, C. 1988. The evolutionary basis of ecological amplitude of plant species. Ph.D Thesis, Liverpool University.

JONES, D. A. AND WILKINS, D. A. 1971. Variation and Adaptation in Plant Species. Heinemann, London.

KRUCKeberG, A. L. AND WU, L. 1992. Copper tolerance and copper accumulation of herbaceous plants colonizing inactive California copper mines. Ecotox. Envir. Safety, 23, 307-319.

MACNAIR, M. R. 1979. The genetics of copper tolerance in the yellow monkey flower, Mimulus guttatus. I. Crosses to non-tolerants. Genetics, 91, 553-563.

MACNAIR, M. R. 1981a. The uptake of copper by families of Mimulus guttatus differing in genotype primarily at a single copper tolerance locus. New Phytol., 88, 723-730.

MACNAIR, M. R. 1981b. The tolerance of higher plants to toxic materials. In: J. A. Bishop and L. M. Cook (eds), Genetic Consequences of Man Made Change. Academic Press, London, pp. 177-208.
MACNAIR, M. R. 1983. The genetic control of copper tolerance in the yellow monkey flower, Mimulus guttatus. Heredity, 50, 283-293.

MACNAIR, M. R. 1987. Metal tolerance in mines in Devon: a natural evolutionary experiment. Nature in Devon, 8, 29-44.

MACNAIR, M. R., MACNAIR, V. E. AND MARTIN, B. E. 1989. Adaptive speciation in Mimulus: an ecological comparison of $M$. cupriphilus with its presumed progenitor, M. guttatus. New Phytol., 112, 269-279.

MACNAIR, M. R. AND WATKINS, A. D. 1983. The fitness of the copper tolerance gene in Mimulus guttatus in uncontaminated soil. New Phytol., 95, 133-137.

MCNEILLY, T. 1968. Evolution in closely adjacent populations. III. Agrostis tenuis on a small copper mine. Heredity, 23, 99-108.

MCNEILLY, T. 1979. Studies on the ecological genetics of heavy metal tolerant plant populations. Aquilo, ser Zool., 20, 17-25.

MCNEILLY, T. AND BRADSHAW, A. D. 1968. Evolutionary processes in populations of copper tolerant Agrostis tenuis Sibth. Evolution, 22, 108-118.

ROBINSON, N. J. AND THURMAN, D. A. 1986. Involvement of metallothionein-like copper complex in the mechanism of copper tolerance in Mimulus guttatus. Proc. R. Soc. Lond. $B, \mathbf{2 2 7}, 493-501$.

SAlt, D. E., Thurman, D. A., TOMSETt, A. B. AND SEwell, A. K. 1989. Copper phytochelatins of Mimulus guttatus. Proc. R. Soc. Lond. B, 236, 79-89.

SCHAT, H. AND TEN BOOKUM, w. M. 1992. Genetic control of copper tolerance in Silene vulgaris. Heredity, 68, 219-229.

SEARCY, K. B. AND MACNAIR, M. R. 1990. Differential seed production in Mimulus guttatus Fisch. ex DC in response to increasing concentrations of copper in the pistil by pollen from copper tolerant and sensitive sources. Evolution, 44, 1424-1435.

SEARCY, K. B. AND MULCAHY, D. L. 1985. The parallel expression of metal tolerance in pollen and sporophytes of Silene dioica (L.) Cairv., S. alba (mill.) Krause and Mimulus guttatus DC. Theor. Appl. Genet., 71, 231-237.

STRANGE, J. AND MACNAIR, M. R. 1991. Evidence for a role for the cell membrane in copper tolerance in Mimulus guttatus. New Phytol., 119, 383-388.

VICKERY, R. K. JR., PHILLIPS, D. R. AND WONSAVAGE, P. R. 1986. Seed dispersal of Mimulus guttatus by wind and deer. Am. Mid. Nat., $116,206-208$.

WASER, N. M., VICKERY, R. K. JR., AND PRICE, M. v. 1982. Patterns of seed dispersal and population differentiation in Mimulus guttatus. Evolution, 36, 753-764.

WILSON, J. B. 1988. The cost of heavy metal tolerance: an example. Evolution, 42, 408-413. 